\title{
Death Portrayals in Edgar Allan Poe's 'The Masque of the Red Death': A Transtextual Study in Relation to the Holy Qur'an and Arabic Literary Heritage
}

Atef Adel Almahameed, Nusaiba Adel Almahameed*, Reem Rabea, Imad-edden Nayif M A'leade Alshamare

Al-Hussein Bin Talal University, Jordan

Corresponding Author: Nusaiba Adel Almahameed, E-mail: n.almahameed@yahoo.co.uk

\section{ARTICLE INFO}

Article history

Received: April 25, 2018

Accepted: August 30, 2018

Published: October 31, 2018

Volume: 9 Issue: 5

Advance access: August 2018

Conflicts of interest: None

Funding: None

\author{
Kay words: \\ Edgar Allan Poe, \\ The Qur'an, \\ Arabic, \\ Intertextuality, \\ Transtextuality
}

\begin{abstract}
This paper is aimed at interpreting Edgar Allan Poe's 'The Masque of the Red Death' (1842) and its portrayal of death in relation to the Holy Qur'an and Arabic literary heritage. This reading provides new insights into the understanding of the story. The paper argues that Poe's story and its depictions of death allows for a transtextual analysis as it is based, for a significant extent, on stories from the Qur'an, the holy book of Islam, which informs of the inevitability of death. In addition, the anatomic study of the story investigates the influence of Arabic literary heritage and its role in arousing the writer's imagination. Scholarly work notes that Poe's story follows many traditions of gothic fiction and is often analysed as an allegory about the inevitability of death, though some critics advise against an allegorical reading. Apart from scholarly work on the story, the paper is purported at rereading the story and explores the transtextual connections and affiliations between the story's portrayal of death and what Qur'an tells about death. There are striking moments of parallelism between the two sources on the notion of death although the story's oriental and Islamic references to death shine implicitly through and never made explicit nor directly copy the Qur'anic verse or the Arabic literary sources. Therefore, the paper digs deeply into the story to explore how its representations of death are influenced and shaped by the Holy Qur'an and Arabic literary heritage.
\end{abstract}

\section{INTRODUCTION}

'The Masque of the Red Death' is probably one of Poe's (1809-1849) most popular and widely read and criticised short stories. The story is originally written and published as 'The Masque of the Red Death: A Fantasy' in 1842. It offers a fantastic vision of man's failed attempts to avoid or escape death. The story narrates the tale of Prince Prospero who attempts to avoid a dangerous plague, known as the Red Death, by hiding in his abbey. The story's events take place in his castellated abbey where the Prince, along with other wealthy nobles, hosts a masquerade ball. He and his guests take a secure refuge in this "happy and dauntless and sagacious" (Poe, 1920, 175) abbey to escape the "Red Death", a terrible plague that swept over the land. Within this walled abbey, seven rooms are decorated with different colours: blue, purple, green, orange, white, and violet except for the last that is decorated in both black and crimson red colour. The seventh room is illuminated by a scarlet light, "a deep blood color" (177) cast from its stained-glass windows. One night and in the midst of their revelry which lasts for six consecutive months, a mysterious figure in a dark, blood-splattered robe resembling a funeral shroud disguised as "Red Death" victim, enters and makes his way through each of the rooms. Prospero dies after he confronts with this stranger whose "costume" proves to contain nothing tangible inside it; the guests also die in turn (182).

The story's fantastical embodiment of man's deeply haunted fears of death, frantic condition of wipe-out and his attitude towards the end of life challenge readers to delve deeply inside their consciousnesses and unravel their dark and realistic deep fears of the inevitability of death. The story's rich portrayal of darkness, death and decay is considered in various ways and received multiple readings and interpretations that attempt to identify and discover the origins of man's portrayal of the deadly disease and the nature of human traumatic attitudes and fears behind.

This paper aims to provide an alternative transtextual reading of the story in relation to the Holy Qur'an and the Arabic literary and heritage. This textual absorption is self-evident in the writer's portrayals in 'The Masque of the Red Death'. The story's imbedded references to death and its inevitability is indicative of Poe's noteworthy influence and profound inspiration by Qur'anic stories. Before turning into the paper's illustrative account of the story's elucidation and its significant imported portrayals, it is certainly worth looking through the body of literary criticism and scholarship.

Poe is one of the most prolific writers of the gothic horror genre and his story is often read as macabre tale. Most 
scholarly work on the story present it as an exemplary that typifies gothic horror fiction and is noted for its remarkable incorporation of its key dark elements (Agassi and Jarvie, 2008, 70). Critics such as Agassi and Jarvie recognises the story's incorporation of particular gothic tropes, gothic imagery and certain haunting and nightmarish qualities. They note that this story is one of Poe's most terrific gothic tales where plague destroys a party in progress $(2008,70)$. In the same vein, Sova (2007) contends that the story is a typical horror narrative and gothic fantasy that explores the gothic trope of death in the way it focuses on very ghastly imagery of blood and death while the personification of the "Red Death" imparts an element of the supernatural. Sova comments that the story offers a personification of "the deadly red death disease that he characterizes as being incurable, fatal, and inescapable, much as his contemporaries viewed tuberculosis" (110). The story is shrouded in horror and extremely preoccupied with mad fear of death and for the most part due to existing common gothic components including the supernatural. Freud (2003) already considered the strong relation between the uncanny and the death, affirming that "to many people the acme of the uncanny is represented by anything to do with death, dead bodies, revenants, spirits and ghosts" (148). In this respect, it is further emphasised that death cannot be represented directly in literature but materialises through the figure of the ghost: "the ghost is the fiction of our relation to death made concrete" (Jackson, 2003, 68). Death is still viewed as one of the largest fears and mysteries of mankind, and as such remains the greatest source of horror literature.

The story and its portrayal of death, supernatural figures and ghosts, on the other hand, is considered an epitome of symbolism and allegory. The story is often analysed as an allegory of the inevitability of death, man's fear of sin, madness, death and the end of the world. The story closes with the line that sums it all up, "And Darkness and Decay and the Red Death held illimitable dominion over all” (185). Hence, the story has another story within and a hidden meaning. Death is brought by a ghastly mysterious figure who suddenly shows up putting an end to human extravagant fantasies: "The figure was tall and gaunt, and shrouded from head to foot in the habiliments of the grave" (182). Prince Prospero and his people unmask the disguised guest and finally discover its intangible form so to realise that it is the Red Death itself but sadly it is too late as they all fall dead.

Some critics also observe the significant and rich symbolic nature of Poe's tale. Their research has focused on the symbolism of the seven colours used in the tale. For instance, Parks (2010) notes this symbolic feature by linking it to Poe who in his youth "may have seen people as colors, or associated certain colors with certain individuals" (98). The symbolism of blood is also discussed. In this particular vein, Maul (2002) argues that in many instances blood is defined as "the juice of life"; however, in 'The Masque of Red Death' blood means the exact opposite, "it is the bringer of Death" (5).

Furthermore, the story's fictionalisation and dramatisation of death is seen by some critics as an allegory of man's deep terror of death. The story does not only explore the reality of death and its extreme inevitability and unstoppability but also depicts it as a terrifying phenomenon. In this particular setting, Pereira (2017) examines how time and space are juxtaposed to obtain the effect of terror. She notes that Poe's story and its fantastic notions of death are primarily and significantly linked to space. Her analysis aims to investigate the extent to which the space of the body functions as a space of memory and the relation between this space and the effect of terror (195). Pereira notes that the characters are constantly haunted by the terror of death particularly the juxtaposition of past and present that is responsible for this effect of terror. This obsession can range from a character to a supernatural event or death itself (196).

This paper purports to tackle the story and its portrayal of death but from a different perspective. It is intended to compare Poe's explicit as well as implicit references to the notion of death to verses of the Holy Qur'an and certain sources of Arabic literature. This paper argues that the imaginative experience of death constructed in Poe's 'The Mask of the Red Death' is influenced and bears unprecedented resemblance to the Holy Qur'an and some sources of Arabic literature. This transtextual reading aspires mainly to reveal the story's various depictions of the inevitability as well as the annihilative nature of death as it is based, for a key extent, on stories from the Holy Qur'an. Moreover, this analytic reading provides new insights on the interesting influence of Arabic literary heritage and its role in conjuring up the writer's imagination. The study explores certain prominent moments of parallel between the two sources on the specific notion of death which, for the most part, shine implicitly through and never straightforwardly or directly copy the original source of influence. The first part of this transtextual analysis focuses on the story's manifestations of death by considering some transtextual references to Arabic literature, some of which, fall under Genett's paratextuality. This paratextual element, remarkably noted in the phrase used in the title of the story, observes this transtextual relationship with the Arabic literary heritage. The second part of the study considers the story's transtextual adaptation of the content of some Qur'anic verses on the inevitability of death. Most of these adaptations are in the form of transformation of the original Qur'anic stories. Doing so, the study presents a few examples that are transtextual with the Qur'anic verses and illuminate their implications in the story.

\section{POE, ARABS AND ISLAM}

Poe is a predominant figure of gothic fiction and a master of horror and mystery stories. His contribution to American gothic fiction is profound and foundational as an early innovator and "an author of the very first horror books" (ZapałaKraj, 2015, 2). He also presents a distinguished example of an American writer profoundly touched and inspired by the Qur'anic stories and the Arabic literary heritage, which serve as a controlling metaphor for Poe's body of writing. Beyond Gothicism, affiliations with the Qur'an and the Arabic literary heritage were prevalent in his written corpus. His fascination arose from an in-depth reading of second-hand materials and translations rather than original texts. 
The awareness of Arabic literature and culture particularly during the late $18^{\text {th }}$ and early $19^{\text {th }}$ centuries became the popular taste and the spirit of the age in Europe and America. People enjoyed reading oriental stories and appreciated oriental objects. For example, Moore's oriental romances, 'Lalla Rookh' and 'Aliciphor', published in 1840 in Graham's Magazine, revealed the general excitement about things of oriental nature. Also, Galland's (1704) translation of the massive and widely popular 'Arabian Nights' is yet another notable example. In the same vein, Attar (2014) observes Poe's drawing from the Arabic and Islamic culture. She points out the wide popularity and the powerful influence of 'The Arabian Nights' and its tales that fuelled the English romantic imagination. She adds that oriental sources were accessible including "pre-Islamic poetry, Arabic history and literature, Muslim mystic poetry, and numerous oriental tales" (14). Poe's interest in the Arabic culture serves as one part of a wider and more prevailing therein American interest. Hutchisson (2011) mentions that newspapers accounts of the expeditions to the area captured American's imaginative thirst for travelling and discovery (38). Poe's interest began in one of his early works, 'Eleven Tales of the Arabesque' (1833) which observes the impact of the culture of the Middle East on his literary imagination. Arif's (2014) analysis of some of Poe's poems highlights Poe's fascination with the Orient as a significant backdrop which shaped his vision to become "a eulogizer to the Oriental wisdom" (113).

The Holy Qur'an was a great inspiration for Poe. Many of his poems embrace Qur'anic imagery. This influence also shines thoroughly through his poetry. Three of his poems first published in 1831 collection namely; 'Israfel', 'To Helen', and 'The Doomed City' all centre on Qur'anic imagery. 'Israfel', for instance, presents Poe's skilful employment of Qur'anic references and characters notably, the character of Israfel as well the allusion to doomsday. Concerning Qur'anic imagery, Poe's long and most acknowledged poem, “Al Aaraaf" offers a remarkable example of an overflowing text filled with Qur'anic imagery. The poem is deeply indebted to the Our'anic narratives, imagery, and prophesies. It notably reveals Poe's deep interest and affectionate inclination to the Islamic Orient. The Poem's depictions of Qur'anic stories evidently trace Poe's assimilation and stresse the effect of the Qur'an on his writings. The poem is entitled, 'Al Aaraaf' (1829) emulating the name of 'Al Aaraaf' chapter in the Qur'an. 'Al Aaraaf' is originally an Arabic word and in the Quranic interpretation, it stands for the region between Heaven and Hell. It similarly portrayed in Poe's Poetry and Tales. Poe (1984) writes: "Al Aaraaf of the Arabians, a medium between Heaven and Hell where men suffer no punishment and yet do not attain that tranquility \& even happiness which are supposed to be the characteristic of heavenly enjoyment" (1368). According to his definition, 'Al Aaraaf' is the elevated place where dead souls between Heaven and Hell neither suffer any sort of punishment nor find peace and happiness promised for the righteous.

This Qur'anic spell is also prevalent in 'The Masque of the Red Death', the subject of this paper, which offers a striking example of Poe's interesting influence by Qur'anic stories.
The plentiful implicit Quranic imagery and the arousing parallel found in the story can be illustrated by Poe's reading of the Qur'an in the translation made by the Orientalist George Sale in 1734. Einboden notes that the Qur'an was a standard reading and widely recognised among American writers during the Federalist period. He comments:

Qur'anic quotations are to be found diffused throughout the texts of America's literary patriarchs, permeating the public works and private papers of not only Emerson, but also contemporaries, successors and rivals such as Washington Irving (1783-1859) and Edgar Allan Poe (1809-1849), building an architecture of Islamic allusion within the very foundations of early US letters $(2009,2)$.

The Holy Qur'an, as Einboden explains, plays an important role in Poe's early poetic development. Indeed, Poe's poetry is "indebted not only to Islamic reference, but to specifically Qur'anic allusion” (7). The story demonstrates this remarkable fascination significantly noted in its reworking of the Qur'anic stories and the Arabic references. In this particular story, Poe reflects on the notion of death as an extremely horrific and inevitable truth.

\section{TRANSTEXTUALITY IN EDGAR ALLAN POE'S 'THE MASQUE OF THE RED DEATH'}

Recent decades have witnessed a growing tendency to study culture in all its forms in terms of texts and intertextual relations as transtextuality has been increasingly recognised as a permeating literary phenomenon. The concept of intertextuality which emerged during the 1960 s is a critical key tool in literary criticism. As a term, intertextuality was first coined by the French linguist Julia in a way to illustrate her complete belief in the mutability and movement of texts. The first usage of the term was in Kristeva's 'Word, Dialogue and Novel' (1966). Kristeva's idea of intertextuality views the text as a dynamic site which makes it to read as an assimilation and transformation of another text or group of other texts. "A text", Kristeva (1980) explains, "is a permutation of texts, an intertextuality: in the space of a given text, in which several utterances, taken from other texts, intersect and neutralize one another" (66). According to Kristeva, the literary text is not a unilinear entity but a heterogeneous combination of texts. Kristeva resists the idea of a text as a singular or autonomous entity created by a single author but an assemblage of prior texts. Her notion of intertextuality focuses on the idea of shared dialogue amid pieces of literature as she notes that "each word (text) is an intersection of words (texts) where at least one other word (text) can be read" (66).

Intertextuality which denotes the way in which texts gain meaning through their referencing is originated in the context of poststructuralist theories of language. Kristeva's enunciation of the theoretical term intertextuality was based on combining Saussurean and Baktinian theories. The idea of intertextuality was first found in Saussure's (18571913) theories of semiology which speculate how signs derive their meaning within the structure of a text. Bakhtin's (1895-1975) followed Saussure but was interested in the social aspects of language and ideas of dialogism - a theory which suggests a continual dialogue within the works of lit- 
erature. Saussure was first alarmed by this interactive aspect of language and the relational nature of the word and how its meaning is constructed. Bakhtin has later asserted the nature of intertextual dialogue or the dialogic nature of texts. $\mathrm{He}$ asserts that the text is not just an individual verbal entity but a social phenomenon. Building on Bakhtanian's dialogism, Kristeva coined the new term, intertextuality, in describing the intertextual dialogue and interactions among texts and so the whole conception of intertextuality came into use. When a writer borrows from another writer or author, he does this either to strengthen the text and to highlight the meaning or to employ a specific vision provided by the author.

Kristezva's terminology labelled as intertextuality is called transtextuality by Genette (1997). Transtextuality is, basically, Genette's version of intertextuality. Genette builds on Kristeva's critique of intertextuality and widens the importance of the potential dynamics that lay within the text by pointing out the relation between various texts. Genette believes that a text can never stand alone, as he defines transtextuality as "all that sets the text in a relationship, whether obvious or concealed, with other texts" $(1997,1)$. Genette's transtextuality or textual transcendence is proposed as a more inclusive term that covers the entire field of intertextuality and provides five subdivisions of the transtextual phenomenon.

\section{TRANSTEXTUALITY IN RELATION TO ARABIC LITERARY HERITAGE}

The theory of transtextuality or transtextual transcendence upon which this study is based is meant to highlight the intentional connections and conscious textual transcendences between Poe's narrative tale 'The Mask of the Red Death' and (now dissolved) verses of the Holy Qur'an as well as some sources of Arabic literary heritage. In doing so, this paper aims to investigate how the different aspects of intertextuality are utilised in Poe's story. The investigation is purported to unravel to what extent references to the Holy Qur'an and the Arabic literary heritage have been used as well as the effect this process creates in interpreting the story. The transtextual analysis of Poe's narrative will benefit from Genette's theory of transtextuality and its subdivisions. The analysis of the transtextual features of the story uses Genette's terms including intertextuality, paratextuality and hypertextuality.

To this end, the story makes several transtextual references to some Arabic literary heritage which can fall under paratextuality using Genett's terms. Genette divides paratextuality into two subcategories namely "peritext" and "epitext". Genette refers to the "peritext" as one to include elements such as titles, epigraphs, prefaces, captions and notes. Other elements, such as interviews, private letters, and reviews are called the "epitext". The title of "The Masque of the Red Death' provides a remarkable example of paratextuality. The title which is an example of a peritext demonstrates its significance as a decoding tool that uncovers the text itself. Considering the title, one does not look at it as it is given to the story unconsciously, but as a factor helping in interpreting the text and penetrating into its infinites. The title is the point at which the author and reader stop before delving into the text itself (Qațūs, 2001, 33).

The title which Poe gives to his story is something of deliberate misleading. The word "masque" is used ambivalently and with deliberate intention of bemusement. In fictional narratives, the masque usually refers to the covering that disguises and conceals the entire face or most of it. It has many uses including disguising for the purpose of committing a crime; most thieves and criminals wear it, so no one can recognize them. The first word "masque" suggests disappearance of perceptible things. However, using the word with imperceptible or abstract things (in this case death) through metaphoric language (metaphor, metonymy and synecdoche) suggests mystery. Therefore, using this effective form of language violates the normal rule of regular language law and adds an element of surprise to the reader, which in turn awakens their inner vision. This violation of the language law is called displacement (Kohen, 1986, 101-130). The masque is the most acceptable tool to reveal the untold story or the taboo in all its forms. This is evident in Fables in the world narrative heritage such as in 'Animal Farm' by George Orwell (1945) and 'Kalilah and Dimna' by 'Ibn Al-Muqaff'a (756 AD).

The word death, in the literal sense, has no association with the red colour. This is simply because of the abstractness of death which has neither shape, image nor colour. The red colour also has no inherent meaning of death. However; it connotes death once figuratively used. Words and colours often bear cultural and emotional associations or meanings, in addition to their denotations or literal meanings. Literary language is one that reflects, displaces, and deviates from the one familiar to the reader. Therefore, the red colour becomes associated with meanings of danger, warning or death particularly if this displacement occurs, hence, red obviously becomes representative of death. Using the word "red" as a descriptor of "death" in the story stimulates meaning and provides an aesthetic dimension at non-literal level. This aesthetic provocation of new levels of meanings arises out of this unusual combination of the two words. The word "red" is not accompaniment of "death" at the dictionary or literal level. However, this unusual combination provides a remarkable example of displacement that elicits meaning far beyond the straightforward or explicit interpretation of language. This displacement implied by this unique combination stimulates the reader's thinking and provides an aesthetic illusion. In addition, it blends physical reality and its illusion with the connotative aspects of meaning; potential aesthetic functions of language.

Therefore, it can be said that the red colour bears a wide array of associative connotations partly due to its multiple hues. The red colour carries a set of contradictory emotional nuances. Apart from its positive connotations such as calmness and serenity, the intense red colour evokes images of malice, murder and hatred. This conflicting significance surface when the red colour departs from its perceptible connotation in favour of some inherited social relationship that suggests some potential negative connotations including roughness, violence and murder. 
Based on a search made in this study concerning possible usages of the phrase "red death" in Western literature, no old usage was found but in Poe's story in which the phrase made its first appearance. However, the phrase is found to have been used in old Arabic literature and this sets the story in transtextual relationship with the Arabic literary heritage; one of the focuses of this study. This descriptive phrase, "red death", is used by some Arab poets and writers a long time ago. Some examples of the phrase's usage are found in Arabic literature during and after the pre-Islamic era and in various contexts. For example, Al-Hariri said "Even my blue foe commiserated me, will it then be red death?" (quoted in Al-Qazwini, 2007, 193 [our translation]). The metaphoric use of the phrase in this context is to demonstrate the praise of death.

Another usage of the phrase "red death" is also found in 'Attikah bint Nawfal's expression when she describes the bravery of her husband, 'Abdullah Bin Abi Bakar Al-șid$\mathrm{d} \overline{\mathrm{I}} \mathrm{q}$, in the battle. She said: "If spears hurled at him, he faces them until he kills them and so his foe is left red" (Al-Hasan Al-Bașri, 1999, 607 [our translation]). In the same vein, the phrase "red death" is used in Arabic poetry. The poet $A b \bar{U}$ Tammām says: "A man falls at night embracing the clothing of red death dabbled in blood for the sake of gaining the dress of green fine silk in paradise" (Al-Tabrīziy, 1994, 219 [our translation]). This metaphorical use of the "red death" within the context of facing death and afterlife, depicting it as the path to paradise paints a heavenly picture of reward of noble death and blood sacrifice.

In addition, the phrase "red death" is also utilised in one of 'Maqāmāt of Badi ' Al-zamān Al-Hamdhāni' in which the fictional hero recounts: "the black day and the red death" (Al-Hamdhāni, 2002, 288 [our translation]). Colours are imbued with great symbolic power. The red colour and as referred to in the previous discussion and in the context of Arabic culture implies the prevision of death. It is generally associated with the approaching of death, stances of fierceness, violence and brutal murder. The connection that the colour red bears with fierce killing and death implies a psychological impact that transforms this mental representation into a perceptible property that is discernible by the human eye. It is evident that the writer's choice of the title is highly influenced by and communicate the meanings of the "red death" and its implications as found in the context of the Arabic culture and literature. In this context, Poe uses two images that describe death as red; one is perceptible and seen in the portrayal of death as masked figure and another that depicts the psychological death and its implications and associations of blood, brutality and violence.

\section{MANIFESTATIONS OF TRANSTEXTUALITY IN THE HOLY QUR'AN}

Poe's 'The Masque of the Red Death' draws heavily on the Holy Qur'an and this is profoundly evident in its employment of the content of some Qur'anic verses which talk about death. Most of these employments are in the form of reproduction of the original Qur'anic stories within a context that serves the formal and semantic structure that each employment is aiming for. On studying this aspect, therefore, the study presents some models that are transtextual with the Qur'anic verses and refers to the original verses in the Holy Qur'an and illuminate their significances and functions in the story. There are several examples of this transformation and transtextual connection that can be found in the story. A few of them are presented below.

Poe begins his story with an obvious case of transtextuality in relation to the Holy Qur'an. The story opens with " "[t]he Red Death' had long devastated the country". (Poe, 1985, 307). This text observes a transtextual connection, imbedded in its content, with the saying of Allah in the Holy Qur'an. Allah describes death as annihilation and perishing:

And when We decide to destroy a town (population), We (first) send a definite order (to obey Allah and be righteous) to those among them [or We (first) increase in number those of its population] who lead a life of luxury. Then, they transgress therein, and thus the word (of torment) is justified against it (them). Then We destroy it with complete destruction (The Nobel Qur'an, Al-Isrā' 17. 16).

In the verses quoted above appears the first aspect of this manifestation and transtextual affiliation that is apparent in using the phrase "devastated the country" (Poe, 307). This descriptive expression of death that demolishes the village observes a significant parallel not only with the Qur'an but also with the Arabic language where death usually comes coupled with torment, extermination and annihilation. In addition, this phrase is also used in the Holy Qur' an as a metaphor. The Qur'anic phrase is originally, "We decide to destroy a town (population)" as destruction falls upon the people of the village, and they are the ones who are meant by destruction; for they themselves, not the village, who might be disbelievers and liars. The warning, lesson and sermon lie in the destruction of the people and not the destruction of the village itself without its people. However, as implied by the phrase, the act of destruction of the village, without its people, is delayed in order to indicate generality, inclusiveness and briefing, which is the main purpose for which such uses are cited in the Holy Qur'an. This structure helps the writer to describe the plague which inflicts the village provoking horror in the hearts of all of the people as indicative of generality and inclusiveness that agrees with the content of the verse.

The previously mentioned Qur'anic verse explains how in every nation, there are those sybarites who usually indulge themselves in affluence, money, servants and power and live in comfort and luxury until they become slouch. They live in debauchery, disdain values, sanctities and dignities and commit taboos which lead to immoral life. A village is thus doomed and destructed upon adopting some means that lead to its downfall, and so sybarites disperse widely and multiply as the village fails to stop them or even reforms its own system. In the same respect, Sayyid Qutub (1967) explains that those sybarites and delinquent voluptuaries who are to spread debauchery and corruption will lead to the village's ultimate destruction and perishing (20).

This signification that is embedded in the interpretation of the verse is also found and reflected in Poe's story which 
talks about Prince Prospero, the symbol of corruption, tyranny and oppression. Prospero seemingly is indifferent to the suffering and death of people outside his castellated abbey, hiding himself far from the city and the plague. In order to escape the spread of the infectious deadly disease, Prospero invites more than one thousand of his friends among them are healthy knights of his palace, beautiful women and retired ones to stay with him and his entourage in one of his most beautiful churches. Inside the secluded abbey, all means of comfort and entertainment are provided; including dancers, musicians, beautiful ladies, drinks and festivities all of which imply fornication and debauchery.

Another example of significant transtextual connection which observes the writer's influence by the Holy Qur'an, in relation to the notion of death, is where he makes the story based on an important event; the sweeping of the "Red Death". Prospero attempts to survive himself and his entourage, who are not yet afflicted with the horrible disease. They resort to a fortified monastery of high walls and iron gates so that no one is infected by the deadly contagion. As Poe writes that Prospero "retired to the deep seclusion of one of his castellated abbeys [...]. A strong and lofty wall girdled it in. This wall had gates of iron" (Poe, 307). The story's depiction of the imminence of death makes resemblance to what is referred to in the Holy Qur'an. Allah says: "Wheresoever you may be, death will overtake you even if you are in fortresses built up strong and high!" (The Noble Qur'an, An-Nis $\bar{a}$ ' 4. 78). Therefore, their attempts to run away from death shall be doomed to failure and this is obviously evident in Prince Prospero's futile and desperate attempts to escape the "Red Death". Lofty and fortified towers can never avert death because it is both natural and inevitable. Death has nothing to do with the fortification of the place that shelters man. The timing of death is only associated with the term of life and the time estimated by Allah for man's death and the advent of that date.

In the rhetorical sense, attributing the notion of advent or capturing of death is also metaphoric. Referring to death, the above Qur'anic verse uses the word "overtake" that implies the notion of inescapability as well as capturing. Similarly, the story provides a remarkable portrayal that personifies death by comparing it to a monster or mystical beast that chases humans and seizes them. In the same vein, Al-Alusi states:

Expressing the awareness of the passage of death is a warning that reveals the extent to which people try hardly to distant themselves away from the causes of death and its imminent proximity. However, death will approach them through breathing paths and groaning as there is no way to escape it. Death is serious, insistent and persistent; it spares no one soul (2000, 78 [our translation]).

The Qur'anic phrase, "fortresses built up strong and high", indicates the fact that castles are built mainly for a specific purpose which is to prevent death from touching or reaching them. Nonetheless, nothing can stop death from entering these castles. Poe is evidently inspired by the meanings of the above Qur'anic verse that highlight and underscore the idea preoccupying him, namely death, which is the inevitable end of all creatures regardless how long they live, and regardless of any precautions they may take to protect and shelter themselves from death. Nobody, whatever his power, position or rank, can ever escape death. This picture overlaps with other many pictures reflected in the Holy Qur'an for some tyrants who lived long time ago and thought that their power, tyranny and wealth shall keep death away from them.

The story's transtextual affiliation with the Holy Qur'an is also observed in its portrayal of dying, chasing of man, and man's confrontation with death. This connection is evident in Poe's narrative. He tells:

It was then, however, that the Prince Prospero, maddening with rage and the shame of his own momentary cowardice, rushed hurriedly through the six chambers, while none followed him on account of a deadly terror that had seized upon all. He bore aloft a drawn dagger, and had approached, in rapid impetuosity, to within three or four feet of the retreating figure, when the latter, having attained the extremity of the velvet apartment, turned suddenly and confronted his pursuer. There was a sharp cry - and the dagger dropped gleaming upon the sable carpet, upon which, instantly afterwards fell prostrate in death the Prince Prospero (Poe, 310).

The above quoted lines show Poe's apparent drawing on the Qur'anic verse which asserts the fact that no one can escape death: "Verily the death from which you flee will surely meet you" (The Noble Qur'an, Al-Jumu'ah 62. 8). The verse accentuates the reality of death and reminds of the impermanency of life and the irrevocability of death. The verse depicts an extremely turbulent scene to escape death that is ultimately inescapable. In this scene, death is used metaphorically rendering the man's trepidation of facing it. Poe compares death to a monster which chases a man and causes his dread. All man's attempts to run away, or escape death will turn to failure as death is unavoidable; facing or confronting it is inevitable.

Another manifestation of transtextuality is also evident in the story's use of the coal-black "gigantic clock" (Poe, 308). The clock presents a symbol of the transience of life and inevitability of death. In the story, every time the clock strikes and chimes an hour, horror and fear finds its way to the hearts of those who are in the castle, then shortly they return to their busy status in an attempt to distract themselves from the reality of death. At this point, it is worth mentioning that the word 'hour' is mentioned forty-eight times in the Holy Qur'an, eight of which are used to signify the fleetingness of time that in turn implies the ephemerality of life itself. An example of this is found in $A l-A^{\prime}$ râf Surah in which Almighty says: "And every nation has its appointed term; when their term comes, neither can they delay it nor can they advance it an hour (or a moment)" (The Noble Qur'an, 34: 204). In the same token, 'AbŪ Ja'far Al-Nahhās states that: "The 'hour' is specified due to its being the least terms for labelling time" (1988, 379 [our translation]). Additionally, the "hour" is mentioned in different places to refer to doomsday (the end of the world). Explaining the reasons behind naming the doomsday as the 'hour', Alrazi (1999) points out that at doomsday, judgment is so fast as if it takes just one hour. In addition, hour is used in this position particularly because 
doomsday happens suddenly and surprises all creatures just in an hour that nobody knows but Allah (52). Therefore, one central fact of Islamic creed ascertains that humans' life ends with death which interrupts their life in a specified hour. The aim behind mentioning it is to warn those whose hearts are oblivious to the remembrance of Allah and to wake them up from their oblivion, so that the prolongation of life does not entice them. This confirms the inevitability of death and that every human being dies at a specific time that is unchangeable and unavoidable.

It is clearly seen that Poe is fascinated and inspired by the Qur'an and this is evident through utilising some words of the Qur'an and then using them in a similar semantic context. By adopting the main idea of depicting death, Poe removes the borders with the (dissolved) text which imparts to his narrative great amounts of sacred emotions derived from the sanctity of Qur'anic impact. Moreover, Poe's fictional portrayals are enriched with his background knowledge and his artistic ability which enable him to reshape his inspiration but in a new portrayal.

Furthermore, the use of the word 'rain' is yet another example of transtextuality in relation to the Holy Qur'an. The meaning of rain in the story does not refer to familiar meaning of the fall of water. To the contrary, the Qur'anic meaning of rain goes far beyond this and signals immense fear and horror. Poe describes the masked guest's clothing as "dabbled in blood - and his broad brow, with all the features of the face, was besprinkled with the scarlet horror" (Poe, 310). In the same vein, rain is mentioned in the Holy Qur'an in many places to indicate the severity of torment inflicted upon the past disobedient nations. As Allah says: "And We rained down on them a rain (of stones). Then see what the end of the Mujrimun was. (criminals, polytheists and sinners)" (The Noble Qur'an, Al-A'rāf 7. 81).

Allah destroyed Prophet Lot's people with a shower of stones of clay accompanied by deadly rain for their immoral transgression of the bounds of Allah, their arrogant display of sins, and for not responding to the call of their Prophet. Poe's inspiration by the Holy Qur'an is apparent with regard to the Qur'an's implied usage of the meaning of the word rain. Poe's artistic employment of the word rain benefits from this implicative meaning and adds further suspense and excitement to the expression. Poe's words and expressions become consistent with the general purpose of the context and with the underlying feelings of fear and terror. The beauty of intertextuality appears through the difference between the use of the word 'rain' in the Qur'anic script and the story. The Holy Qur'an talks about tangible torment that was inflicted upon the disobedient past nations and was attended by the spectators. However, Poe uses it to refer to psychological and moral dilemmas that arouse horror and fears in their souls.

In addition to the aforementioned examples of transtextuality, the story's closure provides a noticeable case of transtextual connection with the Holy Qur'an. The following two verses stresses the fact of the inevitability of death as in Almighty's saying: "Everyone shall taste death" (The Noble Qur'an, Àl 'Imrān 3.185) and in "Whatsoever is on it (the earth) will perish) (The Noble Qur'an, Ar-Rahamān, 55.26). The previous two verses determine a fact that should settle in the soul and heart of everybody, and which also implies that life is transitory, and its end is unstoppable. So, every soul will perish regardless of its wealth, strength, position in life or deeds be righteous or evil. This meaning corresponds with the ending of Poe's story. Poe closes his tale with the following lines:

And now was acknowledged the presence of the Red Death. He had come like a thief in the night. And one by one dropped the revellers in the blood-bedewed halls of their revel, and died each in the despairing posture of his fall. And the life of the ebony clock went out with that of the last of the gay. And the flames of the tripods expired. And Darkness and Decay and the Red Death held illimitable dominion over all (Poe, 311).

The lines quoted above by which Poe ends his story connect to the two verses in relation to the emphasis of the fact that death is both nonavertable and inescapable. Poe depicts the internal psychological conflict between mind and sensation, underwent by every human towards death. This internal struggle that is an outcome of the human's awareness of the inevitability of death deepens his inner feelings of fear, so one is unable to accept its reality. It can be said that the end of the story reveals three facts related to death; its place, time, and inevitability which the Holy Qur'an stresses in many verses. Concerning place, the Holy Qur'an indicates that everybody will taste death no matter what measures of fortification and protection are followed or taken. Regarding time, the Holy Qur'an confirms the fact that whether a man lives for a short or a long time, death will come in its predetermined time which is unchangeable and cannot be eluded. The story's ending emphasises the third fact about death, i.e., its inevitability. This is apparent when death is compared to a thief who sneaks into a man's life and steals his soul then moves into another man's life and another until the entire mankind perishes.

\section{CONCLUSION}

The paper purports to investigate Poe's gothic tale from a new perspective, delineating the story's portrayals of death in association with the Holy Qur'an and Arabic literary heritage. Previous studies have examined the story's gothic qualities and allegoric nature. The author's nightmarish setting, ghastly imagery and use of the supernatural make it a perfect example of the gothic genre. The story's symbolic nature also appeals to critics as a great example of allegory. Nonetheless, this paper proves valid undertaking particularly taking into account explicit and implicit references to death. Through depicting this image of death, Poe is evidently profoundly inspired by some of the ideas and meanings of death as found in the Holy Qur'an and some Arabic literary sources.

The writer is distinctly overwhelmed by the transtextuality that depends on dissolution and absorption so he is satisfied to give some quick hints associated with the Qur'anic text. This kind of transtextuality is extremely deep as it is based on implications and embedded hints hardly noticed by 
any reader unless s/he is familiar with the contents of the absent texts. The forms of transtextuality used by Poe do not negatively reflect the Qur'anic text and its connotations thereof, but it shows that the writer had an immense knowledge and background of the diverse mass Arabic and Islamic culture.

\section{REFERENCES}

Agassi, Joseph, and Jarvie, Ian. A Critical Rationalist Aesthetics. The Netherlands: Rodopi, 2008.

Al-Aluosiy, AbŪ al-Faḍl Shihāb Al-Din Muhammad. Ruoḥ

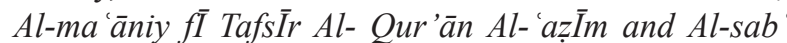
Al-mathānI. TaḥqĪq Muḥammad Aḥmad Al- amad, and 'Omar Abdul Salām al-Salāmiy. Beirut dār 'iḥyā' alturāth al-'arabiy, $1^{\text {st }}$ ed., 2000.

Al-Hamdhāni, AbŪ Al- ḍfạ̣il Aḥmad bin Al-Husayn bin Yaḥyā Badi Al-zamān. Maqāmāt Badi al-zamān al-Hamdhāni. Introduction and explanation by AlShaykh Muḥammad 'Abdo, Beirut: Dār al-Kutub al-'Ilmiyyah, Beirut, $1^{\text {st }}$ ed., 2002.

Al-Hasan Al-Bașri, Sadr al-Din Ali bin Abi al-Faraj. Alhamāsah Al-baṣriyyah. taḥqĪq: 'ādil sulayān jamāl, Cairo: Al-khānijīi, $1^{\text {st }}$ ed, 1999.

Al-Naḥḥās 'AbŪ Ja'far. Ma 'āny al- Qur'ān. TaḥqĪq Muḥammad 'Ali al- șābŪni. Mecca: Umm al-Qura University, 1988.

Al-Rāziy 'AbŪ 'Abdullah Muhammad bin 'Omar. Tafs $\bar{I} r$ Al$k a b \bar{I} r$. Beirut: dār 'ihyā' al-turāth al-'arabiy, $3^{\text {rd }}$ ed., 1999.

Al-Qazwini Muhammad ibn 'Abd Al-Rahman ibn 'Umar Abu al-Ma'āli Jalāl al-Din al-Khatib. Al-iydhāh fí 'ulŪm Albalāghh: Alma 'āniy \& Al-bay 'à $k \& B a d \bar{I}$ '. Reviewed by 'imād Basyuoni Zaghluol. Bierut: Dār Al-Arqam Bin Abi Al-Arqam, 1 ${ }^{\text {st }}$, ed, 2007.

Al-TabrĪziy. Al-Khațiyb. Shariḥ Diwān AbŪ Tammām. Beirut, Dār al-Kitāb al- 'arabiy, $2^{\text {nd }}$ ed., 1994.

Arif, Hafiz M. "Image of the Orient in Edgar Allan Poe's poems". Asian Journal of Multidisciplinary Studies 2.6 (2014): 113-116.

Attar, Samar. Borrowed Imagination: The British Romantic Poets and their Arabic-Islamic Sources. Lanham, MD: Lexington Books, 2014.

Einboden, Jeffrey. “The Early American Qur'an: Islamic Scripture and US Canon". Journal of Qur'anic Studies. 11.2 (2009): 1-19.
Freud, Sigmund. The Uncanny. Trad. David McLintock. Londres: Penguin Books, 2003.

Hutchisson, James M. "Storytelling, Narrative Authority, and Death in 'The Thousand and Second Tale of Scheherazade"". Edgar Allan Poe: Beyond Gothicism. Ed. Hutchisson. Newark: University of Delaware Press, 2011. 37-48

Genette, Gerard. Palimpsests: Literature in the Second Degree. Translated by Channa Newman and Claude Doubinsky. Lincoln and London: University of Nebraska Press, 1997.

Jackson, Rosemary. Fantasy: The Literature of Subversion. Londres e Nova Iorque: Routledge, 2003.

Kohen, Jān. Bbinyat Allugh Alshi'riyyah. Translated by Muḥammad Al-Wali, and Muḥammad Al-'umari. Al-dār al-baydhāa: Dār Toubqāl lilnashir, $1^{\text {st }}$ ed., 1986.

Kristeva, Julia. "Word, Dialogue, and Novel". Desire in Language: A Semiotic Approach to Literature and Art. Ed. Leon S. Roudiez. Trans. Thomas Gora et al. New York: Columbia U. P, 1980. 64-91.

Maul, Kristina. About Edgar Allan Poe's - "The Masque of Red Death”. Germany: Grin Verlag, 2002.

Parks, Edd Winfield, Edgar Allan Poe as Literary Critic. Athens: The University of Georgia Press, 2010.

Pereira, Jaqueline Pierazzo. "Entre Memória E Esquecimento: O Espaço-Tempo Do Terror Em "The Masque of the Red Death" De Edgar Allan Poe”. Estudos Anglo Americanos. 46.1. (2017): 195-213

Poe, Edgar Allan. Works of Edgar Allan Poe. New York: Gramercy Books, 1985.

------. Poetry and Tales. New York: The Library of America. 1984.

Qațūs, Bassām, Syimyāa Al-'ukwān. Amman: wazārah al-thaqāfah, $1^{\text {st }}$ ed., 2001.

Sayyid Quțub. fI żilāl Al- Qur'ān. Beirut Dār al-'arabiyyah, $4^{\text {th }}$ ed, 1967.

Sova, Dawn. Critical Companion to Edgar Allan Poe: A Literary Reference to His Life and Work. New York, NY: Infobase Publishing, 2007.

The Noble Qur'an. Translated by Dr. Muhammad Taqi-udDin Al-Hilali and Dr. Muhammad Muhsin Khan. Madinah: King Fahd Complex for the Printing of the Holy Qur'an, 1984.

Zapała-Kraj, Marta. Edgar Allan Poe's Contribution to American Gothic. Germany: Grin Verlag Gmbh, 2015. 